\title{
Perceived Learning and Satisfaction in a Blended Teacher Education Program: An Experience of Malaysian Teacher Trainees
}

\author{
Leila Karimi \& Tunku Badariah Tunku Ahmad \\ International Islamic University Malaysia, Malaysia
}

\begin{abstract}
Blended learning, as a new approach to education, is rapidly being adopted by educational institutions for the purpose of teacher education or teacher training. This study reports the results of a survey exploring the relationships between perceived learning and satisfaction in a blended teacher education program among three different groups of specialization at the Institute of Education, International Islamic University Malaysia (IIUM). This study was mainly exploratory in nature, employing specifically the quantitative research method, utilizing crosssectional survey as the method of data collection. The respondents consisted of 170 teacher trainees who were randomly selected through quota sampling. The instrument used to collect data was a modified questionnaire that measured the respondents' perception of learning and satisfaction in the blended teacher education program. The respondents reported high levels of perceived learning and satisfaction toward the blended teacher education program. The results showed positive and moderate correlation between perceived learning and satisfaction, while there was no statistically significant difference among all groups of teacher trainees' perception of learning and satisfaction.
\end{abstract}

Keywords: Teacher education program; Blended learning; Perceived learning; Student satisfaction

\section{Introduction}

The term blended learning is a new approach to education and it is being used with increasing frequency in the academia. A common definition of blended learning as a form of distance education based on Internet technology, refers to the integration of traditional face-to-face instructional method with the self-study online instructional resources which makes it possible to enjoy the potential of both teaching methods (Voos, 2003; Harding, Kaczynski, \& Wood, 2005; Allen \& Seaman, 2006; Garrison \& Vaughan, 2008). According to Rooney (2003), blended learning has been identified by the American Society for Training and Development (ASTD) as one of the top ten trends to emerge in the knowledge delivery industry and it is emerging as a major global trend in educational context (Allen \& Seaman, 2006). Recently, some researchers have suggested that blended learning promises effectively boost the core of teaching and learning (Gómez \& Igado, 2008). Others (e.g., Garrison \& Kanuka, 2004) indicate that it can provide the learner with higher levels of learning. Certain conducted researches have shown that blended learning has been very successful over the past years and it has the potential to yield better results than traditional and online learning alone (Balci \& Soran, 2009; Deperlioglu \& Kose, 2010; Munson, 
2010). For instance, Allen and Seaman (2011) pointed out that, one-third of all academic leaders continue to believe that the learning outcomes for blended learning are inferior to those of faceto-face instruction. "Going beyond the barriers of time and location" is one of the other best potentials of blended learning (Jusoff \& Khodabandelou, 2009, p. 80).

Due to benefits that blended learning programs bring such as maximizes effectiveness, foster the quality of teacher-learner interaction, feedback instantly and the other advantages (Gómez \& Igado, 2008; Alebaikan \& Troudi, 2010) many educational settings have changed their delivery methods to blended programs to take advantage of the best pedagogical techniques of mixing online and face-to-face learning (Godambe, Picciano, Schroeder, \& Schweber, 2004).

Moreover, over the recent years, blended learning approach has been the fastest- growing trend among many educational settings in the UK (Sharpe, Benfield, Roberts, \& Francis, 2006), North America (Bonk, Kim, \& Zeng, 2006), Australia (Eklund, Kay, \& Lynch, 2003) and the USA (Allen \& Seaman, 2011). Blended learning is gaining popularity in Asia Pacific as well. In this region, higher educational institutions have joined their western counterparts in adopting blended learning. According to Economist Intelligence Unit (EIU) report, countries such as Korea ranked 5th, followed by Singapore in 6th position while Taiwan, Japan, Malaysia, Thailand and China ranked 16th, 23rd, 25th, 36thand 46th, respectively in their blended learning readiness (UNIT, 2008).

In Malaysian higher education institutions blended teaching and learning approach has increasingly attracted great interest and support (Puteh \& Hussin, 2007; Azizan, 2010; Siew-Eng, Ariffin, \& Rahman, 2010; Embi, 2011). Malaysian institutions offer a wide variety of blended courses to the students. For example, at the time of this study, 17 universities and colleges in Malaysia are offering teacher education courses (Hotcourseabroad, 2012). Some of them are delivering these courses to the teachers in the form of blended learning. The IIUM is one of the universities where the blended program is implemented for the purpose of teacher training. It is for the first time, the IIUM has offered a Bachelor's Degree level in Education (Primary and Secondary School) through blended learning starting from 2011 to 2015.

Although, a considerable amount of literature has been published on the blended learning far little attention has been paid by prior empirical researches specifically focused on blended teacher education program, (So \& Brush, 2008; Alebaikan \& Troudi, 2010; Sorden, 2011). Blended teacher education program is still in its infancy stage at Malaysian higher education institutions and IIUM. That being the case, not much research has been done in this field (see Zher Ng \& Raja Hussain, 2010). On the other hand, among those little researches on the blended teacher education program, no attention has been paid to its effectiveness in training teachers.

Moreover, several key factors are considered to be significant in a blended program. Among those factors, students' perceived learning and satisfaction are two critical success factors which are worth examining in depth in such program, while limited previous researches were located that included both constructs (Richardson \& Swan, 2003; So \& Brush, 2008). Therefore, this study measures both these constructs in order to obtain greater insights into possible relationship among them in the blended teacher education program. 
Lewis (2011) indicated that perceived learning is the extent to which a certain level of knowledge obtained on the new learning recognized by students. Ewell, Lovell, Dressler, and Jones (1994) pointed out that "there is a considerable literature concerned with establishing the validity of student self-reports about cognitive outcomes" (p. 23). Additionally, Alavi, Marakas, and Yoo (2002) define perceived learning as "changes in the learner's perceptions of skill and knowledge levels before and after the learning experience" (p. 406). Thus, in a blended teacher education program, it is crucial to know about student teachers' learning reports because it provides instructors with an opportunity to make necessary revisions. These changes could be sought to ensure the quality of the learning experience as well as to improve the learner's experience.

On the other hand, Chang and Fisher (2003) suggested that students' satisfaction has been reported to be a very significant component for the successful completion of the course. It is an important key of success or failure of any new innovation or in teaching and learning environments. Those studying in the field of blended learning have also agreed that student satisfaction is a baseline requirement for the successful implementation of blended learning programs. It contributes to effective learning in a blended learning environment. Therefore, it is also considered to be an important element in measuring the quality of a blended teacher education program. Although a number of advantages have been recognized in implementing blended learning, insufficient learning satisfaction emerged to be a barrier to the successful adoption of blended courses (So, 2006). Additionally, students' satisfaction as well as their perception of learning plays a significant role in assessing the effectiveness of the educational method applied in a blended learning environment (Akkoyunlu \& Soylu, 2008). In this regard, understanding student teachers' satisfaction is a fundamental step that may provide insights into the enhancing student teachers' perception of learning. Therefore, it is important to examine satisfaction and perceived learning as two of many factors leading to an effective and successful blended learning program in higher education.

Thus, this study was primarily designed to gain an in-depth understanding of the relationship between perceived learning and satisfaction in the blended teacher education program among three different specializations including TESL, ISED and GUIDE at the Institute of Education. To achieve this general purpose the study outlined several research questions mentioned below.

1. What levels of satisfaction and perceived learning do IIUM teacher trainees in a blended learning program report?

2. Is there any significant relationship between teacher trainees' perception of learning and satisfaction in the IIUM blended teacher education program?

3. Is there any statistically significant difference between TESL, ISED and GUIDE teacher trainees' perception of learning and satisfaction in the IIUM blended teacher education program?

\section{Blended Teacher Education Program in Malaysia}

The government of Malaysia has a vision for the country to become a fully developed nation in every aspect by the year 2020 (Mohamad, 2003). The education policy has been consistent and in 
line with Vision 2020 plan. In order to achieve this, Malaysian National Philosophy of Education demands for developing the potential of individuals in a holistic and integrated manner.

Developing human capital is a top priority of the Malaysian government (Hassan, Hashim, \& Ismail, 2006). However, the challenges faced by educational system in Malaysia, such as: (1) the need for new instructional methods in opposite of unsatisfactory traditional teaching methods in preparing students to move rapidly towards the future. (2) The need for effective and innovative technology integration into teaching and learning activities, (3) the need for student-centered learning and outcome-driven educational approaches, and (4) the need to enhance the development of students' 21st century learning skills, call for conducting teacher education programs to support the national education system and to produce qualified teachers as well as to develop innovative teachers who can overcome the country's educational system problems (Almacen, 2010).

Teacher education and training in Malaysia is conducted for primary and secondary school teachers by $\mathrm{MOE}$ and Ministry of Higher Education (MOHE). Training primary teachers implemented via the Institute of Teacher Education (ITE) (previously known as Teacher Training Colleges) and training the secondary teachers is carried out via the government-funded universities. Teacher Education Division (TED) is a section in the Malaysian Ministry of Education, which supervises teacher education programs in Malaysia. The TED has several parts that aids in its operations. For instance, the Planning and Policy Unit plans and determines the direction of teacher education in Malaysia (Almacen, 2010). Based on the recent Malaysian education scenario, universities have, accordingly, changed their approach to teacher education and training programs. There are numerous institutes and universities in Malaysia where provide both preservice and in-service teachers with teacher education programs. Mohamad, Saud and Ahmad (2011) indicate that in Malaysia teacher education programs are offered via some methods, consists of; Problem-based learning (PBL), Work based learning (WBL), Project based learning (PBL) and Blended learning (BL). In teacher education programs, blended learning is considered as a strategic and effective instructional method with unique features to help improve student teacher's discussion skills, improve their communities of practice, and achieve their course purposes (Means, Toyama, R, Bakia, \& Jones, 2009).

Universities such as IIUM, Universiti Putra Malaysia (UPM), and Universiti Technology MARA (UiTM) offer blended teacher education programs with a wide range of disciplines for busy teachers who are unable to attend campus-based academic programs. The efforts have been made by such universities to provide teachers with the bachelor's degree in various multiple specializations. For instance, Universities such as IIUM, UiTM and UPM offer wide variety of blended education programs to teachers, who would be able to teach in any type of secondary schools. As for the teacher education programs at the universities, almost all of the programs offered are for pre-service teachers. These universities developed blended programs to in-service teachers who are pursuing their bachelor's degree as part of the national agenda for all teachers to have a bachelor's degree (Almacen, 2010).

The programs offered by the IIUM are Teaching English as a Second Language (TESL), Islamic Education (ISED), and Guidance and Counseling (GUIDE). This program intention is to give opportunity for the non-university graduate teachers to increase their academic qualifications and competencies to the first degree, besides fulfilling the demand for the university graduated 
teachers for critical subjects in primary and secondary schools. Through this blended learning program, the Malaysian Ministry of Education is hoping to increase the number of university graduated primary school teachers from currently $28 \%$ to $60 \%$ and $90 \%$ university graduated secondary school teachers (from $89.4 \%$ ) by 2015 , in parallel with the 10th Malaysian Plan. This program is proceeding through $80 \%$ online learning and $20 \%$ face-to-face method. This is because all teachers are working as full time teachers in different schools locations. Thus, the IIUM has sufficient Information and Communication Technology (ICT) facilities to handle distance learning through existing Learning Management System (LMS) (Institute of Education, 2011).

\section{Method}

\section{Sample}

This study was mainly exploratory in nature, employing specifically the quantitative research method, utilizing cross-sectional survey as the method of data collection. This study was primarily designed to examine the relationship between perceived learning and reported student satisfaction in the IIUM blended teacher education program. 200 under-graduate second-year teacher trainees were initially recruited from blended teacher education program in the multiple specializations at the IIUM, Malaysia representing approximately $48 \%$ of the total population. Prior to data collection the procedures and the ethics of conducting research were closely observed and complied by the researcher. Removing 30 cases due to incomplete questionnaires, a total of valid $170(85 \%)$ questionnaires were analyzed. The sample size was divided to $47 \%(n=81)$ for TESL teacher trainees, $29 \%(n=48)$ for ISED teacher trainees and $24 \%(n=41)$ for GUIDE teacher trainees. The gender composition of respondents was less balanced with $69 \%$ female respondents and $31 \%$ male respondents. Ages of the respondents ranged from 25 to 55 . However, the age ranges $25-35$ and $36-45$ account for $\% 97.05$ of the respondents. And the majority of them were in semester 3 .

\section{Instruments}

The instrument used to collect data within this study was a modified questionnaire which consisted of three sections. The first section contained several relevant data on the respondents' demographic information such as gender, age, specialization, and the semester, which was needed to provide descriptive information of the respondents. The other two sections contained a total of 23 items measuring constructs of perceived learning which originally developed by Rovai et al. (2009) with a high internal consistency of 0.79 and satisfaction consisted of 12 items with an alpha level of 0.88 .

\section{Results}

Descriptive statistic (frequencies, percentages, means and standard deviations) were used to describe demographic information of the respondents as well as the levels of perceived learning and satisfaction reported by teacher trainees toward blended program. The data was then 
analyzed with an alpha level of .05 for all significance tests in the study. The Likert-type scales were considered to be interval scales. The Pearson product-moment Correlation Coefficient using Pearson's $r$ was used to examine whether there was a significant statistical relationship between perceived learning and student satisfaction. One-way MANOVA was used to explore the differences among the three different groups of specialization teacher trainees' perceptions toward perceived learning and satisfaction.

\section{Research Question 1}

\section{Levels of Perceived learning}

In this section, the results indicated a high level of perceived learning in blended program. Participants generally agreed with statements describing understanding the content of program as well as the ability of improving classroom practices and student centered lessons from this teacher education program. For example, students generally agreed or strongly agreed with items; I understood the content of this teacher education program well (Perceived Learning \#6), I can now improve my classroom practices from this teacher education program (Perceived Learning \#11) and I can develop student centered lessons (Perceived Learning \#2). Agreement or strong agreement with these items ranged from 91 to 93 as indicated in Table 1.

\section{Levels of Satisfaction}

Overall, the results indicated a high level of satisfaction in blended program. Participants generally agreed with statements describing satisfaction with their learning experience and the instructors in this teacher education program. For example, students generally agreed or strongly agreed with items; my experience in this teacher education program is a useful learning experience (Satisfaction \# 5), I'm happy with my experience in this teacher education program (Satisfaction \# 4) and I'm happy with the instructors in this teacher education program (Satisfaction \# 10). Agreement or strong agreement with these items ranged from 89 to $98 \%$ as indicated in Table 2 .

However, the lowest levels of perceived learning and satisfaction or ranked items mean were related to the learning from and the quality of online discussion in both sections, developing assessment strategies, and the assignments given in this teacher education program. 
Table 1. Survey Results for Items Reflecting Perceived Learning in Percentage

\begin{tabular}{|l|c|c|c|c|c|c|c|c|c|c|c|}
\hline \multirow{2}{*}{ Items Reflecting Perceived Learning } & \multicolumn{2}{l}{\begin{tabular}{l}
\multicolumn{2}{l}{$\begin{array}{l}\text { Strongly } \\
\text { Agree }\end{array}$} \\
\cline { 2 - 12 }
\end{tabular}} & \multicolumn{2}{l}{ Agree } & \multicolumn{2}{l|}{ Unsure } & \multicolumn{2}{l|}{ Disagree } & \multicolumn{2}{l}{$\begin{array}{l}\text { Strongly } \\
\text { Disagree }\end{array}$} & Rank \\
\hline $\begin{array}{l}\text { I understood the content of this teacher } \\
\text { education program well. (Perceived } \\
\text { Learning \#6) }\end{array}$ & 12.4 & 21 & 80.6 & 137 & 6.5 & 11 & 0.6 & 1 & - & - & 93 \\
\hline $\begin{array}{l}\text { I can now improve my classroom } \\
\text { practices from this teacher education } \\
\text { program. (Perceived Learning \#11) }\end{array}$ & 15.9 & 27 & 76.5 & 130 & 7.1 & 12 & 0.6 & 1 & - & - & 92.4 \\
\hline $\begin{array}{l}\text { I can develop student centered lessons. } \\
\text { (Perceived Learning \#2) }\end{array}$ & 8.2 & 14 & 82.9 & 141 & 7.6 & 13 & 1.2 & 2 & - & - & 91.1 \\
\hline
\end{tabular}

Table 2. Survey Results for Items Reflecting Satisfaction in Percentage

\begin{tabular}{|c|c|c|c|c|c|c|c|c|c|c|c|}
\hline \multirow[t]{2}{*}{ Items Reflecting Satisfaction } & \multicolumn{2}{|c|}{$\begin{array}{l}\text { Strongly } \\
\text { Agree }\end{array}$} & \multicolumn{2}{|c|}{ Agree } & \multicolumn{2}{|c|}{ Unsure } & \multicolumn{2}{|c|}{ Disagree } & \multicolumn{2}{|c|}{$\begin{array}{l}\text { Strongly } \\
\text { Disagree }\end{array}$} & \multirow[t]{2}{*}{$\begin{array}{l}\text { Ran } \\
k\end{array}$} \\
\hline & $\%$ & $\mathrm{n}$ & $\%$ & $\mathrm{n}$ & $\%$ & $\mathrm{n}$ & $\%$ & $\mathrm{n}$ & $\%$ & $\mathrm{n}$ & \\
\hline $\begin{array}{l}\text { My experience in this teacher } \\
\text { education program is a useful learning } \\
\text { experience.(Satisfaction \# 5) }\end{array}$ & 36.5 & 62 & 61.8 & 105 & 1.8 & 3 & - & - & - & - & 98.3 \\
\hline $\begin{array}{l}\text { I'm happy with my experience in this } \\
\text { teacher education } \\
\text { program.(Satisfaction \# 4) }\end{array}$ & 24.7 & 42 & 70 & 119 & 4.1 & 7 & 1.2 & 2 & & & 94.7 \\
\hline $\begin{array}{l}\text { I'm happy with the instructors in this } \\
\text { teacher education program. } \\
\text { (Satisfaction \# 10) }\end{array}$ & 26 & 35 & 62.9 & 107 & $\begin{array}{c}15 . \\
3\end{array}$ & 26 & - & - & 1.2 & 2 & 88.9 \\
\hline
\end{tabular}

\section{Research Question 2}

The result of the comparison (Pearson's $r$ ) indicated that 170 teacher trainees taking blended program shows a significant moderate correlation at $p=.000(r=.62$, significant at the 0.05 level, $\mathrm{N}=170$ ). It can be concluded that the correlation between variables is positive and they were statistically significant. The magnitude of correlation between variables was 0.62 which according to Guilford's rules of thumb was a moderate and substantial relationship (see Table 3).

Table 3. Correlational Matrix for Perceived Learning and Satisfaction

\begin{tabular}{llcc} 
Measure & & Perceived Learning & Satisfaction \\
\hline Perceived Learning & Pearson Correlation & - & $0.62^{* *}$ \\
& Sig. (2-tailed) & - & .00 \\
& $\mathrm{n}$ & 170 & 170 \\
\hline Satisfaction & Pearson Correlation & $0.62^{* *}$ & - \\
& Sig. (2-tailed) & .00 & - \\
& $\mathrm{n}$ & 170 & 170 \\
\hline
\end{tabular}

\footnotetext{
**. Correlation is significant at the 0.01 level (2-tailed).
} 


\section{Research Question 3}

A one-way MANOVA was conducted to explore if there were significant differences on the dependent variables included the total scores of perceived learning and total scores of satisfaction by multiple specialization (TESL, ISED and GUIDE). The means and standard deviations of each dependent variable by multiple specializations are listed in Table 4. The goal of One-way MANOVA analysis is to look for an effect of one or more IVs on several DVs at the same time. Results of the analysis indicate that there is no statistically significant difference in the overall perceived learning and satisfaction between three group of participants.

Table 4. Descriptive Statistics

\begin{tabular}{|l|l|r|r|c|}
\hline & Specialization & Mean & Std. Deviation & $\mathrm{N}$ \\
\hline \multirow{5}{*}{ Perceived learning } & ISED & 43.6875 & 3.44659 & 48 \\
\cline { 2 - 5 } & GUIDE & 43.3902 & 3.86573 & 41 \\
\cline { 2 - 5 } & TESL & 43.3086 & 3.08075 & 81 \\
\cline { 2 - 5 } & Total & 43.4353 & 3.37041 & 170 \\
\hline \multirow{5}{*}{ Satisfaction } & ISED & 50.4583 & 6.01402 & 48 \\
\cline { 2 - 5 } & GUIDE & 49.5610 & 6.29702 & 41 \\
\cline { 2 - 5 } & TESL & 48.2222 & 6.45949 & 81 \\
\cline { 2 - 5 } & Total & 49.1765 & 6.33517 & 170 \\
\hline
\end{tabular}

The Multivariate Tests table is used to find the actual result of the one-way MANOVA. To determine whether the one-way MANOVA was statistically significant it is required to look at the "Sig." column. Wilks' Lambda was used as the statistical test. The results indicated that Wilks' Lambda $=$ $0.972, F(4,332)=1.206, p=0.308$ (see Table 5). Therefore, the research question three was not supported. Thus, results of this analysis indicated that there was no statistically significant difference among ISED, GUIDE and TESL teacher trainees' perception of learning and satisfaction in the IIUM blended teacher education program.

Table 5. Multivariate Tests

\begin{tabular}{|c|c|c|c|c|c|c|c|c|c|}
\hline \multicolumn{2}{|c|}{ Effect } & \multirow{2}{*}{$\begin{array}{l}\text { Value } \\
.028\end{array}$} & \multirow{2}{*}{$\begin{array}{c}\mathrm{F} \\
\\
\\
\\
1.20 \\
5 \\
\end{array}$} & \multirow{2}{*}{$\begin{array}{l}\text { Hyp } \\
\text { o df } \\
4.00\end{array}$} & \multirow{2}{*}{$\begin{array}{c}\text { Error } \\
\mathrm{df}\end{array}$} & \multirow{2}{*}{$\begin{array}{l}\text { Sig. } \\
.308\end{array}$} & \multirow{2}{*}{$\begin{array}{c}\text { Partial } \\
\text { Eta } \\
\begin{array}{c}\text { Squar } \\
\text { ed }\end{array} \\
.014\end{array}$} & \multirow{2}{*}{$\begin{array}{c}\text { Nonce } \\
\text { nt. } \\
\text { Param } \\
\text { eter }\end{array}$} & \multirow{2}{*}{$\begin{array}{c}\text { Obs } \\
\text { erve } \\
d \\
\text { Pow } \\
\text { er } \\
.378\end{array}$} \\
\hline $\begin{array}{l}\text { Specializat } \\
\text { ion }\end{array}$ & Pillai's Trace & & & & & & & & \\
\hline & Wilks' Lambda & .972 & $\begin{array}{c}1.20 \\
6\end{array}$ & 4.00 & 332.00 & .308 & .014 & 4.826 & .378 \\
\hline & $\begin{array}{l}\text { Hotelling's } \\
\text { Trace }\end{array}$ & .029 & $\begin{array}{c}1.20 \\
7\end{array}$ & 4.00 & 330.00 & .307 & .014 & 4.829 & .378 \\
\hline & $\begin{array}{l}\text { Roy's Largest } \\
\text { Root }\end{array}$ & .029 & $\begin{array}{c}2.40 \\
6\end{array}$ & 2.00 & 167.00 & .093 & .028 & 4.812 & .480 \\
\hline
\end{tabular}


The results of the One-way MANOV as for the dependent variables are presented in the Tests of Between-Subjects Effects, as shown in Table 6. Results of this analysis showed that, specialization has not statistically significant effect on both perceived learning $(F(2,167)=0.193 ; P>0.05$; partial $\varepsilon 2=0.002)$ and satisfaction scores $(F(2,167)=2.04 ; P>0.05$; partial $\varepsilon 2=0.024)$.

Table 6. Tests of Between-Subjects Effects

\begin{tabular}{|c|c|c|c|c|c|c|c|c|c|}
\hline Source & $\begin{array}{c}\text { Dependent } \\
\text { Variable }\end{array}$ & $\begin{array}{c}\text { Type III } \\
\text { Sum of } \\
\text { Squares }\end{array}$ & $\mathrm{df}$ & $\begin{array}{c}\text { Mean } \\
\text { Square }\end{array}$ & $\mathrm{F}$ & Sig. & $\begin{array}{c}\text { Partial } \\
\text { Eta } \\
\text { Squar } \\
\text { ed }\end{array}$ & $\begin{array}{c}\text { Noncen } \\
\text { t. } \\
\text { Parame } \\
\text { ter }\end{array}$ & $\begin{array}{c}\text { Obser } \\
\text { ved } \\
\text { Power } \\
\text { c }\end{array}$ \\
\hline $\begin{array}{c}\text { Special } \\
\text { ization }\end{array}$ & $\begin{array}{c}\text { Perceived } \\
\text { learning }\end{array}$ & 4.436 & 2 & 2.218 & .193 & .824 & .002 & .387 & .080 \\
\cline { 2 - 11 } & Satisfaction & 135.32 & 2 & 67.66 & 2.043 & .133 & .024 & 4.087 & .417 \\
\hline
\end{tabular}

\section{Discussion}

The results of the study indicate that high levels of perceived learning and satisfaction reported by student teachers in IIUM teacher education program. It seems that blended learning can enhance student teachers perception of learning. Respondents mentioned that they were successful in the learning process and were pleased with their experience when they enrolled in blended learning environments. They experienced an increased collaborative activities and interaction between student and student as well as student and instructor through tasks, and activities. Student teachers had pleasure and enjoyment with the learning experience and accomplishment in the blended learning environment. These finding correspond with the results of a great deal of the previous work in this field reporting high level of perceived learning and satisfaction among teacher trainees in a blended teacher education program such as Sorden (2011); Top (2012) Lim, Morris, \& Kupritz (2006); Martínez-Caro and Campuzano-Bolarín (2011) and Naaj, Nachouki and Ankit (2012)study. This findings also are consistent with those of Mackey and Ho (2008) study who found that high level of perceived learning regarding to Web usability in blended learning program. However, the finding of the current study do not support the study conducted by Wells and Dellinger Wells and Dellinger (2011) who have been unable to demonstrate a higher level of perceived learning in blended learning in compare to online learning.

The findings also indicate that a moderate and substantial relationship (0.62) between perceived learning and satisfaction in blended teacher education program. These finding also match with the results of Richardson and Swan (2003) who investigated the relationship between students' perceptions of learning and satisfaction. Likewise, the finding of the current study was in line with Arbaugh and Rau's (2007) study who found a positive and statistically significant relationship between perceived learning and satisfaction. Similarly, this study reiterates Lewis (2011) study finding that showed there is a significant relationship between satisfaction and perceived learning in blended environment. So and Broush (2008) examined the relationships of the students' perceived learning and satisfaction in a blended collaborative learning environment. The researchers found statistically positive significant relationship between perceived learning, and satisfaction. Finally, the current study confirm the study of Yilmaz and Orhan (2010) who 
investigated the satisfaction levels of the pre-service teachers in respect to their learning approaches in a blended learning environment. The findings revealed that pre-service teachers were in general highly satisfied with the blended learning environment.

Finally, the result of the study indicate that there was no statistically significant difference among ISED, GUIDE and TESL teacher trainees' perception of learning and satisfaction in the blended teacher education program. This finding corroborates the ideas of de Liaño, León, \& PascualEzama (2012) who suggested that there are no differences between satisfaction and different group of students. However, the findings of a part of their study which investigate the difference of perceived learning between different groups of students were not supported by the current study. de Liaño et al. (2012) found that there is a significant difference between the groups of students and their perceived learning. However, the finding of the current study do not support the previous research of Arbaugh and Rau s' (2007) who found that there are statistically significant differences between students' perceived learning and delivery medium satisfaction with online courses which differ by course discipline. This finding further not supports the idea of disciplinary effect on student's satisfaction and their learning with blended learning format (Chew, 2009).

\section{Conclusion}

As higher education institutions particularly in Malaysia progressively implement blended programs, more and more questions arise pertaining to the effectiveness of blended learning and how much students satisfied with this new approach. For this reason, the current study looked into to investigate perceived learning and satisfaction in a blended teacher education program among teacher trainees of three groups of specialization at IIUM.

Blended learning programs offer an innovative environment for communication among students and instructors and at the same time allows the instructors to develop courses, which are studentcentered and allow teamwork (Nyachae, 2011). Even though blended program allows easy access to the content and instructor, anytime from anywhere, it has to be appropriately designed to engage the students in order to promote the desired learning. It is imperative for educators to know how to create a learning environment where all key areas work simultaneously.

The finding of the current study indicated that student teachers reported high level of perceived learning and satisfaction in the blended program. The finding showed student teachers ranked high the statements that describing understanding the content of program as well as the ability of improving classroom practices and student centered lessons from this teacher education program. Likewise, teacher education students identified that blended learning has been useful learning experience as the most important indicator in satisfaction with blended teacher education program. However, a surprising finding of the current study appears in online discussion boards that showed student teachers learned very little from discussion boards as well as they were less satisfied with this factor of blended delivery format. Therefore, the empirical findings in this study provide a new and contrast understanding of blended learning environment in teacher education programs particularly from Malaysian point of view. 
Moreover, the findings indicate that there is a moderate relationship between the perceived learning and satisfaction among student teachers in the blended teacher education program. The major conclusion that can be drawn from this part of the study is to confirm that there is a moderate link between the learning and satisfaction that a student perceives in a blended teacher education program. While, the researcher expected to see very dependable relationship between two construct, however the finding according to (Field, 2009) was acceptable. Therefore, the present study provided additional evidence with respect to perceived learning and satisfaction as more important factors that contribute the blended teacher education success.

Furthermore, the findings of the study showed that there was no statistically significant difference among ISED, GUIDE and TESL teacher trainees' perception of learning and satisfaction in the IIUM blended teacher education program. These findings indicated that the subject matter is not important item in blended learning environments. These findings also are especially important now to control operating cost to reduce budgets of designing in different blended learning environments for different disciplinary. Because based on the findings of the current study discipline doesn't matter in the blended learning environments regarding to contribute high perceived learning and high level of satisfaction among student teachers in this kind of environment.

Because it is a relatively new approach, more research is needed on blended learning in general, especially in blended teacher education programs particularly in Malaysia. This study would likely have yielded a much fuller perspective if qualitative data had been included and the study had a mixed-method research design. Including an extensive amount of qualitative research lead to support and properly interpret the quantitative data.

\section{References}

Abdul Razak, Z. \& Sanmugam, S. (2010). Teacher trainees' attitude and motivation towards using the Internet as resource for ESL classroom (Unpublished manuscript). Retrieved on 3 July 2012 from http://eprints. utm.my/11176/1/Teacher_Trainees\%E2\%80\%99_Attitude_And_ Motivation_Towards_Using.pdf

Ajayi, L. (2009). An exploration of pre-service teachers' perceptions of learning to teach while using asynchronous discussion board. Educational Technology \& Society, 12(2), 86-100.

Akkoyunlu, B. \& Soylu, M. Y. (2008). A study of student's perceptions in a blended learning environment based on different learning styles. Educational Technology \& Society, 11(1), 183-193.

Alavi, M., Marakas, G. M., \& Yoo, Y. (2002). A comparative study of distributed learning environments on learning outcomes. Information Systems Research, 13(4), 404-415.

Alebaikan, R. \& Troudi, S. (2010). Blended learning in Saudi universities: Challenges and perspectives. Research in Learning Technology, 18(1), 49-59.

Allen, I. E. \& Seaman, J. (2006). Making the grade: Online education in the United States. Needham, MA: The Sloan Consortium. 
Allen, I. E. \& Seaman, J. (2011). Going the distance: Online education in the USA 2011. Wellesley MA: Babson Survey Research Group.

Almacen, B. (2010). Teacher training program: The Malaysian perspective. Retrieved on 3 July 2012 from http://independent.academia.edu/DrBayaniAlmacen/Books/408843/Teacher_ Training_Program_The_Malaysian_Perspective

Altun, A., Gulbahar, Y., \& Madran, O. R. (2008). Use of a content management system for blended learning: Perceptions of pre-service teachers. Turkish Online Journal of Distance Education, 9(4). Retrieved on 3 July 2012 from http://tojde.anadolu.edu.tr/tojde32/index.htm

Arbaugh, J. B. (2001). How instructor immediacy behaviors affect student satisfaction and learning in web-based courses. Business Communication Quarterly, 64(4), 42-54.

Arbaugh, J. B. \& Rau, B. L. (2007). A study of disciplinary, structural, and behavioral effects on course outcomes in online MBA courses. Decision Sciences Journal of Innovative Education, 5(1), 65-95.

Azizan, F. Z. (2010). Blended Learning in Higher Education Institution in Malaysia. Paper presented at the Proceedings of Regional Conference on Knowledge Integration in ICT (pp. 454-466). Kolej Universiti Islam Antarabangsa Selangor (KUIS). Malaysia.

Balci, M. \& Soran, H. (2009). Students 'opinions on blended learning. Turkish Online Journal of Distance Education, 10(1), 21-35.

Bonk, C. J., Kim, K. J., \& Zeng, T. (2006). Future directions of blended learning in higher education and workplace learning settings. In C. J. Bonk \& C. R. Graham (Eds.), Handbook of blended learning: Global perspectives, local designs. San Francisco: Pfeiffer.

Chamberlin, S. A. \& Moon, S. M. (2005). Model-eliciting activities as a tool to develop and identify creatively gifted mathematicians. Prufrock Journal, 17(1), 37-47.

Chang, V. \& Fisher, D. L. (2003). The validation and application of a new learning environment instrument for online learning in higher education. In M. S. Khine \& D. L. Fisher (Eds.), Technology-rich learning environments: A future perspective (pp. 1-20). Singapore: World Scientific Publishing.

Chew, E. (2009). A blended learning model in higher education: A comparative study of blended learning in UK and Malaysia (Unpublished doctoral dissertation). University of Glamorgan.

Collopy, R. M. \& Arnold, J. M. (2009). To blend or not to blend: online and blended learningenvironments in undergraduate teacher education. Issues in Teacher Education, 18(2), 85-101.

de Liaño, B. G. G., León, O. G., \& Pascual-Ezama, D. (2012). Research participation Improves student's exam performance. The Spanish Journal of Psychology, 15(2), 544-550.

Deperlioglu, O. \& Kose, U. (2010). The effectiveness and experiences of blended learning approaches to computer programming education. Computer Applications in Engineering Education, 19(1), 1-15.

Dziuban, C., Hartman, J., Moskal, P., Sorg, S., \& Truman, B. (2004). Three ALN modalities: An institutional perspective. In J. Bourne \& J. C. Moore (Eds.), Elements of quality online education: Into the mainstream (Vol. 5, pp. 127-148)). Needham: Sloan-Consortium. 
Institute of Education. (2011). Blended learning in International Islamic University Malaysia (Unpublished manuscript). International Islamic University Malaysia.

Eklund, J., Kay, M., \& Lynch, H. M. (2003). e-learning: Emerging issues and key trends-A discussion paper. Australian National Training Authority (ANTA).

EL-Deghaidy, H. \& Nouby, A. (2008). Effectiveness of a blended e-learning cooperative approach in anEgyptian teacher education program. Computers \& Education, 51(3), 988-1006.

Embi, M. A. (2011). e-Learning in Malaysian institutions of higher learning: Status, trends and challenges. Paper presented at the International Lifelong Learning Conference (ICLLL 2011), Kuala Lumpur, Malaysia.

Ewell, P. T., Lovell, C. D., Dressler, P., \& Jones, D. P. (1994). A preliminary study of the feasibility and utility for national policy of instructional "good practice" indicators in undergraduate education. Washington, DC: U.S. Government Printing Office.

Garrison, D. R. \& Kanuka, H. (2004). Blended learning: Uncovering its transformative potential in higher education. The internet and higher education, 7(2), 95-105.

Garrison, D. R. \& Vaughan, N. D. (2008). Blended learning in higher education: Framework, principles, and guidelines. San Francisco: John Wiley \& Sons.

Godambe, D., Picciano, A. G., Schroeder, R., \& Schweber, C. (2004). Faculty Perspective. Paper presented at the Sloan-C Workshop on Blended Learning. Chicago, IL.

Gómez, J., \& Igado, M. (2008). Blended Learning: The Key to Success in a Training Company. International Journal of Instructional Technology and Distance Learning, 5(8). Retrieved on 3 July 2012 from http://www.itdl.org/Journal/Aug_08/index.htm

Harding, A., Kaczynski, D., \& Wood, L. (2005). Evaluation of blended learning: Analysis of qualitative data. Paper presented at the Uniserve Science Blended Learning Symposium (pp56-61). The University of Sydney.

Hassan, A., Hashim, J., \& Ismail, A. Z. H. (2006). Human resource development practices as determinant of HRD climate and quality orientation. Journal of European Industrial Training, 30(1), 4-18.

Hong, L. (2008). Blending online components into traditional instruction in pre-service teacher education: The good, the bad, and the ugly. International Journal for the Scholarship of Teaching and Learning, 2(2) 1-14.

Hotcourseabroad. (2012). 17 universities and colleges in Malaysia offer teacher training courses, Retrieved on 3 July 2012 from http://www.hotcoursesabroad.com/study/trainingdegrees/malaysia/teacher-training-courses/loc/114/cgory/o3-3/sin/ct/programs.html

Jusoff, K., \& Khodabandelou, R. (2009). Preliminary study on the role of social presence in blended learning environment in higher education. International Education Studies, 2(4), 79-86.

Lewis, J. (2011). The computer ate my classroom: Assessing student interactions, perceived learning, and satisfaction in online community college career technical education courses (Unpublished doctoral dissertation). The University of Southern Mississippi, ProQuest LLC. 
Lim, D. H., Morris, M. L., \& Kupritz, V. W. (2006, February). Online vs. blended learning: Differences in instructional outcomes and learner satisfaction. Paper presented at the Academy of Human Resource Development International Conference (AHRD). Columbus, $\mathrm{OH}$.

Lock, J. (2006). New image: online communities to facilitate teacher professional development. Journal ofTechnology and Teacher Education, 14(4), 663-678.

Mackey, T. P. \& Ho, J. (2008). Exploring the relationships between Web usability and students' perceived learning in Web-based multimedia (WBMM) tutorials. Computers \& Education, 50(1), 386-409.

Martinez-Caro, E. \& Campuzano-Bolarin, F. (2011). Factors affecting students' satisfaction in engineering disciplines: traditional vs. blended approaches. European Journal of Engineering Education, 36(5), 473-483.

Means, B., Toyama, Y., R, M., Bakia, M., \& Jones, K. (2009). Evaluation of evidence-based practices in online learning: A meta-analysis and review of online-learning studies. Washington, DC: U.S. Department of Education.

Mohamad, M. (2003). Globalisation and the new realities. Subang Jaya, Malaysia: Pelanduk.

Mohamad, M. M., Saud, M. S., \& Ahmad, A. (2011). The need in training and retraining for TVET teachers in Malaysia. Journal of Technical Education and Training, 1(1), 51-57.

Munson, C. E. (2010). Assessment of the efficacy of blended learning in an introductory pharmacy class. Ph.D. 3408047, University of Kansas, United States. Retrieved on 3 July, 2012 from http://search.proquest.com/docview/577644575?accountid=27932 ProQuest Dissertations \& Theses (PQDT) database.

Naaj, M. A., Nachouki, M., \& Ankit, A. (2012). Evaluating Student Satisfaction with Blended Learning in a Gender-Segregated Environment. Journal of Information Technology Education: Research, 11(1), 185-200.

Nyachae, J. N. (2011). The effect of social presence on students' perceived learning and satisfaction in online courses (Ph.D. thesis). West Virginia University. ProQuest Dissertations \& Theses (PQDT) database.

Puteh, M. \& Hussin, S. (2007). The role of Malaysian government it policies \& e-learning in the tertiary sector. Paper presented at the National E-Community Seminar on Bridging the Digital Divide: Malaysia's Initiative. Kuala Lumpur, Malaysia.

Richardson, J. C. \& Swan, K. (2003). Examing social presence in online courses in relation to students' perceived learning and satisfaction. Journal of Asynchronous Learning Networks, , $7(1), 68-88$.

Rooney, J. E. (2003). Blending learning opportunities to enhance educational programming and meetings. Association Management, 55(5), 26-32.

Rovai, A. P., Wighting, M. J., Baker, J. D., \& Grooms, L. D. (2009). Development of an instrument to measure perceived cognitive, affective, and psychomotor learning in traditional and virtual classroom higher education settings. The Internet and Higher Education, 12(1), 7-13. 
Schlager, M., Fusco, J., \& Schank, P. (2002). Evolution of an online education community of practice. In K. A. Renninger \& W. Shumar (Eds.), Building virtual communities: Learning and change in cyberspace (pp. 129-158). New York: Cambridge University Press.

Sharpe, R., Benfield, G., Roberts, G., \& Francis, R. (2006). The undergraduate experience of blended e-learning: A review of UK literature and practice, Retrieved on 1 June 2012 from http:// www.heacademy.ac.uk/projects/detail/Ir_2006_sharpe

Sher, A. (2009). Assessing the relationship of student-instructor and student-student interaction to student learning and satisfaction in Web-based online learning environment. Journal of Interactive Online Learning, 8(2), 102-120.

Siew-Eng, L., Ariffin, S. R. B., \& Rahman, S. B. (2010). Diversity in education using blended learning in Sarawak. US-China Education Review, 7(2), 83-88.

So, H. J. (2006). Examining the relationships among collaborative learning, social presence and satisfaction in a distance learning environment (Unpublished doctoral dissertation). Indiana University, Indiana.

So, H. J. \& Brush, T. A. (2008). Student perceptions of collaborative learning, social presence and satisfaction in a blended learning environment: Relationships and critical factors. Computers \& Education, 51(1), 318-336.

Sorden, S. (2011). Relationships among collaborative learning, social presence and student satisfaction in a blended learning environment. ProQuest. (UMI Number: 3490523)

Tabachnick, B. G. \& Fidell, L. S. (2007). Experimental designs using ANOVA. Belmont, CA: Thomson.

Top, E. (2012). Blogging as a social medium in undergraduate courses: Sense of community best predictor of perceived learning. The Internet and Higher Education, 15(1), 24-28.

Unit, E. I. (2008). The future of higher education: How technology will shape learning. Retrieved 26 June, 2012 from http://www.eric.ed.gov/ERICWebPortal/search/detailmini.jsp?_nfpb $=$ true\&_\&ERICExtSearch_SearchValue_0=ED505103\&ERICExtSearch_SearchType_0=no\&acc no $=$ ED505103

Voos, R. (2003). Blended learning-whatisitand where mightittake us? Sloan-C View, 2(1), 2-5.

Wells, M. I. \& Dellinger, A. B. (2011). The effect of type of learning environment on perceived learning among graduate nursing students. Nursing Education Perspectives, 32(6), 406-410.

Wingard, R. G. (2004). Classroom teaching changes in web-enhanced courses: A multi-institutional study. Educause Quarterly, 27(1), 26-35.

Yilmaz, M. B. \& Orhan, F. (2010). Pre-service English teachers in blended learning environment in respect to their learning approaches. The Turkish Online Journal of Educational Technology, 9(1), 157-164.

Correspondence: Leila Karimi, Institute of Education, International Islamic University Malaysia, Jalan Gombak, Selayang, Selangor, Malaysia 